\title{
HUBUNGAN PENGETAHUAN, SIKAP DAN PERILAKU BIDAN DESA TERHADAP KANKER LEHER RAHIM DAN PENCEGAHANNYA DI KABUPATEN SRAGEN
}

\author{
Ismail Joko Sutresno ${ }^{1}$, Ova Emilia $^{2}$, Shinta Prawitasari ${ }^{3}$
}

\begin{abstract}
Background: Cervical cancer (cervix) is the second most common type of cancer in women, with an estimated of 530,000 new cases and more than 270,000 deaths each year. In 2012, cervical cancer cases in Central Java was 2,259 cases. Cervical cancer is easily recognizable and can be prevented with screening. A village midwife as the closest healthcare provider to the community is expected to function better in encouraging the prevention of cervical cancer.if they receive appropriate knowledge and attitude toward screening.
\end{abstract}

Objective: to understand the correlation of knowledge, attitude and behavior of village midwife against cervical cancer and its prevention in Sragen district.

Method: This analytic study is using quantitative and qualitative approach. Quantitative studies was done with cross-sectional study. The population of this research were 208 village midwifes from 20 sub-districts in Sragen and the subjects were 118 midwives whom randomly sampled. Data were analyzed using univariate and bivariate analysis. The qualitative study was done using depth interview.

Result and Discussion: There is no correlation between age, level of education as well as work duration with their knowledge about cervical cancer prevention ( $P=0.787 ; 0.344 ; 0.822)$; there is no correlation between village midwives' knowledge with their behavior towards cervical cancer prevention $(P=0.664)$; there is no correlation between the village midwives' attitudes and behavior towards prevention of cervical cancer $(P=0.460)$. Qualitative results support the quantitative results.

Conclusion: There is no correlation between village midwives' knowledge, attitudes and behavior towards cervical cancer prevention.

Keywords: Cervical cancer, knowledge, attitude, behavior

\section{INTISARI}

Latar Belakang: Kanker leher rahim (serviks) merupakan jenis kanker kedua yang paling umum pada perempuan, dengan perkiraan 530.000 kasus baru setiap tahun dan lebih dari 270.000 perempuan meninggal akibat kanker leher rahims. Kasus kanker leher rahim di Provinsi Jawa Tengah pada tahun 2012 adalah 2.259 kasus. Kanker leher rahim mudah dikenali dan dapat dikendalikan bila dilakukan pencegahan secara baik. Bidan desa sebagai orang terdekat dengan masyarakat diharapkan dapat berfungsi lebih baik dalam mendorong pencegahan kanker leher rahim apabila pengetahuan dan sikap bidan desa terhadap kanker leher rahims dan pencegahannya baik.

Tujuan: Untuk mengetahui hubungan pengetahuan, sikap dan perilaku bidan desa terhadap kanker leher rahim dan pencegahannya di Kabupaten Sragen.

Metode: Penelitian ini bersifat analitik dengan menggunakan pendekatan kuantitatif dan kualitatif. Pendekatan kuantitatif menggunakan Studi Potong Lintang (Cross Sectional Study). Populasi penelitian adalah 208 Bidan desa di 20 kecamatan yang ada di Kabupaten Sragen dimana 118 diambil sebagai

RSUD Sragen, Jawa Tengah

Departemen Obstetri \& Ginekologi, FK-UGM/RSUP DR. Sardjito, Yogyakarta 
sampel secara acak. Analisis data dengan univariat dan bivariat. Pada studi kualitatif dilakukan dengan menggunakan wawancara mendalam.

Hasil dan Pembahasan: tidak ada hubungan antara usia, pendidikan dan masa kerja bidan desa terhadap pencegahan kanker leher rahims $(P=0,787 ; 0,344 ; 0,822)$; tidak ada hubungan antara pengetahuan bidan desa dengan perilaku bidan desa terhadap pencegahan kanker leher rahims $(P=0,664)$; tidak ada hubungan antara sikap bidan desa dengan perilaku terhadap pencegahan kanker leher rahims $(P=0,460)$. Hasil kualitatif mendukung hasil kuantitatif.

Kesimpulan: Tidak ada hubungan antara pengetahuan, sikap dan perilaku bidan desa terhadap pencegahan kanker leher rahims.

Kata kunci: kanker leher rahim (serviks), pengetahuan, sikap, perilaku

\section{PENDAHULUAN}

Kanker leher rahim (serviks) merupakan masalah kesehatan yang penting bagi perempuan di seluruh dunia. Kanker ini adalah jenis kanker kedua yang paling umum pada perempuan, dengan perkiraan 530.000 kasus baru dan lebih dari 270.000 perempuan meninggal akibat kanker leher rahims tiap tahun. ${ }^{1}$

Di Indonesia diperkirakan ditemukan 40.000 kasus baru kanker leher rahim setiap tahunnya. Menurut data kanker berbasis patologi di 13 pusat laboratorium patologi, kanker leher rahims merupakan penyakit kanker yang memiliki jumlah penderita terbanyak di Indonesia, yaitu lebih kurang 36\%. ${ }^{2}$

Prevalensi kanker di Provinsi Jawa Tengah pada tahun 2012 adalah sebagai berikut : kanker leher rahim (serviks) sebesar 0,007\% dan tertinggi di Kota Magelang sebesar 0,071\%; kanker payudara sebesar $0,013 \%$ dan tertinggi di Kota Pekalongan sebesar 0,215\%; kanker hati sebesar 0,008\% dan tertinggi di Kabupaten Rembang sebesar 0,23\%; kanker paru 0,006\% dan tertinggi di Kabupaten Rembang sebesar 0,23\%. ${ }^{3}$

Bidan desa memiliki tugas meliputi pendidikan antenatal, persiapan menjadi orang tua serta kesehatan reproduksi perempuan, Keluarga Berencana dan asuhan terhadap anak ${ }^{4}$

Bidan desa diharapkan dapat memberikan pendidikan dan pencegahan terhadap kanker leher rahim kepada masyarakat di wilayahnya, sehingga harus memiliki pengetahuan, sikap dan perilaku yang baik terhadap kanker leher Rahim dan pencegahannya.

Kanker leher rahim merupakan kanker yang mudah dikenali dan dapat dikendalikan bila dilakukan pencegahan secara baik. Berdasarkan latar belakang tersebut maka timbul pertanyaan penelitian bagaimanakah hubungan antara pengetahuan sikap dengan perilaku bidan desa terhadap kanker leher rahim dan pencegahannya di Kabupaten Sragen? Tujuan penelitian ini adalah (1) memahami pengetahuan, sikap dan perilaku bidan desa, (2) melakukan analisis hubungan usia, masa kerja dan pendidikan dengan perilaku bidan desa, (3) melakukan analisis hubungan pengetahuan dengan perilaku bidan desa, serta (4) melakukan analisis hubungan sikap dengan perilaku bidan desa terhadap kanker leher rahim dan pencegahannya di Kabupaten Sragen.

\section{METODE}

Penelitian ini bersifat analitik menggunakan pendekatan kuantitatif dan kualitatif. Metode kuantitatif diperlukan untuk mendapatkan deskripsi hubungan pengetahuan, sikap dan perilaku bidan desa terhadap kanker leher rahim/ serviks dan pencegahannya.

Pendekatan kuantitatif menggunakan Studi Potong Lintang (Cross Sectional Study) dimana 
dinamika korelasi antara faktor-faktor risiko dengan efek diukur dengan cara pendekatan, observasi atau pengumpulan data sekaligus pada suatu saat (point time approach)..$^{5}$

Pendekatan kualitatif digunakan pada penelitian ini Karena metode kualitatif sangat berguna, mengingat metode ini dapat dilaksanakan sebagai komplementer pendekatan kuantitatif, yang dalam pelaksanaannya bersifat simplikasi. ${ }^{6}$

Pada penelitian ini menggunakan teknik wawancara mendalam. Kelebihan yang dimiliki penelitian kualitatif antara lain peneliti dapat memperoleh jawaban yang mendalam, sehingga didapatkan pemahaman yang lebih dalam dan pada teknik wawancara perorangan memungkinkan peneliti melihat hubungan antara kelompok perilaku dan keputusan serta tindakan masyarakat tertentu.

Populasi dalam penelitian ini adalah bidan desa yang ditempatkan di seluruh desa Kabupaten Sragen berjumlah 208 desa di 20 kecamatan yang ada di Kabupaten Sragen. Sampel dalam penelitian ini menggunakan Cluster Sampling. Untuk penentuan sampel menggunakan tabel penentuan jumlah sampel dari Isaac dan Michael yang memberikan kemudahan penentuan jumlah sampel berdasarkan tingkat kesalahan 1\%, 5\% dan $10 \%$. Peneliti menggunakan tingkat kesalahan $10 \%$ untuk menentukan sampel Jadi sampel dalam penelitian ini adalah sebanyak 118 sampel. ${ }^{7}$

Alat pengumpulan data yang digunakan pada penelitian ini adalah menggunakan kuesioner sebagai alat ukur metode pengumpulan data kuantitatif yang dibuat oleh peneliti dan observasi langsung.

\section{HASIL DAN PEMBAHASAN}

Dilihat dari usia, responden usia 25-30 tahun sebanyak 60 responden (50,8\%). Menurut Mantra, bidan merupakan umur tenaga kerja
(18-45 tahun) dengan kategori dewasa muda. Berdasarkan uraian tersebut dapat disimpulkan bahwa sebagian besar responden berada pada kategori usia dewasa muda dimana pada usia tersebut responden dapat berisiko tinggi terinfeksi kanker leher rahims. ${ }^{8}$

Dilihat dari pendidikan, mayoritas responden berpendidikan DIII Kebidanan yaitu sebanyak 104 responden $(88,14 \%)$, dapat diartikan bahwa sebagian besar responden memiliki pendidikan kebidanan formal yang cukup tinggi.

Dilihat dari masa kerja bidan, mayoritas responden memiliki masa kerja < 10 tahun sebanyak 58 responden (49,15 \%) sedangkan yang memiliki masa kerja $\geq 10$ tahun sebanyak 50 responden (42,3\%) sehingga mayoritas responden berada pada kategori masa kerja $<10$ tahun dengan rata-rata masa kerja adalah selama 6 tahun. Ini sudah merupakan bekal pengalaman kerja yang cukup untuk bisa menangani kasus kanker leher rahim.

Tabel 1. Pengetahuan bidan desa terhadap pencegahan kanker leher rahim

\begin{tabular}{lcc}
\hline \multicolumn{1}{c}{$\begin{array}{c}\text { Pengetahuan } \\
\text { Bidan Desa }\end{array}$} & Jumlah & $\begin{array}{c}\% \\
\text { Persen }\end{array}$ \\
\hline $\begin{array}{l}\text { Baik } \\
\text { Skor (11-16) }\end{array}$ & 116 & $98,31 \%$ \\
$\begin{array}{lcc}\text { Buruk } \\
\text { Skor (0-10) }\end{array}$ & 2 & $1,69 \%$ \\
\hline Total & 118 & $100 \%$ \\
\hline
\end{tabular}

Rata-rata skor pengetahuan yang diperoleh responden adalah 9-16. Berdasarkan nilai ratarata tersebut 116 orang (98,31 \%) termasuk dalam kategori baik. Dilihat dari skor tersebut maka bidan desa Kabupaten Sragen telah memiliki bekal materi pencegahan kanker leher rahim diatas rata-rata, dengan demikian minat untuk berperilaku banyak tergantung pada faktor eksternal lainnya. 
Tabel 2. Sikap bidan desa terhadap pencegahan kanker leher rahim

\begin{tabular}{lcc}
\hline \multicolumn{1}{c}{ Sikap } & Jumlah & $\begin{array}{c}\% \\
\text { Persen }\end{array}$ \\
\hline Baik & 112 & $94,1 \%$ \\
Buruk & 6 & $5,1 \%$ \\
Total & 118 & $100 \%$ \\
\hline
\end{tabular}

Bidan desa merupakan ujung tombak pelayanan kesehatan, dalam arti biasanya bidan desa adalah tenaga kesehatan yang paling dekat dengan masyarakat. Jika bidan desa memiliki sikap yang baik terutama dalam pencegahan kanker leher rahim, diharapkan masyarakat dapat mengikutinya sehingga program pencegahan kanker leher rahim dapat terlaksana. Pada penelitian ini sebanyak 112 responden (94,1\%) memiliki sikap yang baik, hal ini menunjukkan bahwa bidan desa telah memiliki keyakinan yang baik untuk dapat melakukan pencegahan kanker leher rahim.

Tabel 3. Perilaku bidan desa terhadap pencegahan kanker leher rahim

\begin{tabular}{lcc}
\hline \multicolumn{1}{c}{ Perilaku Bidan desa } & Jumlah & $\begin{array}{c}\% \\
\text { Persen }\end{array}$ \\
\hline $\begin{array}{l}\text { Baik } \\
\text { Skor (9-16) }\end{array}$ & 108 & $90,8 \%$ \\
$\begin{array}{l}\text { Buruk } \\
\text { Skor (0-8) }\end{array}$ & 10 & $8,4 \%$ \\
\hline Total & 118 & $100 \%$ \\
\hline
\end{tabular}

Perilaku manusia didasari oleh lingkungan sosial dan budaya yang dianutnya. Di pedesaan, bidan desa dianggap orang yang memiliki pengetahuan yang baik utamanya tentang kesehatan, sehingga mempunyai pengaruh yang kuat terhadap perilaku seseorang. Pada penelitian ini sebanyak 108 responden $(90,8$ \%) memiliki perilaku yang baik. Kebiasaan dan perilaku bidan desa mempunyai pengaruh yang kuat terhadap masyarakat sehingga diharapkan jika bidan memiliki perilaku kesehatan yang baik maka masyarakat juga akan memiliki perilaku kesehatan yang baik.

Tabel 4. Hubungan usia bidan dengan perilaku pencegahan kanker leher rahim

\begin{tabular}{lccl}
\hline \multirow{2}{*}{ Usia } & \multicolumn{2}{c}{ Perilaku } & \\
\cline { 2 - 3 } & Baik & Buruk & \\
\hline Senior & 48 & 4 & $\mathrm{P}=0,787$ \\
$\geq 30$ Tahun & $(40,6 \%)$ & $(3,39 \%)$ & \\
\hline Junior & 60 & 6 & \\
$<30$ Tahun & $(50,8 \%)$ & $(5,08 \%)$ & \\
\hline
\end{tabular}

Dari data tabel 4 didapatkan bidan senior maupun junior yang memiliki perilaku yang baik mengenai pencegahan kanker leher rahim sebanyak 108 responden (91,5\%) sehingga dapat disimpulkan bahwa semua bidan desa usia produktif di Kabupaten Sragen memiliki perilaku yang baik mengenai pencegahan kanker leher rahim.

Tabel 5. Hubungan pendidikan bidan dengan perilaku terhadap pencegahan kanker leher rahim

\begin{tabular}{lccc}
\hline \multirow{2}{*}{ Pendidikan } & \multicolumn{2}{c}{ Perilaku } & \\
\cline { 2 - 3 } & Baik & Buruk & \\
\hline \multirow{2}{*}{ D III } & 104 & 9 & P $=0,344$ \\
& $(88,14 \%)$ & $(7,6 \%)$ & \\
\multirow{2}{*}{ D IV } & 4 & 1 & \\
& $(3,3 \%)$ & $(0,8 \%)$ & \\
\hline
\end{tabular}

Berdasarkan data diatas, didapatkan bahwa mayoritas bidan desa dari latar belakang pendidikan DIII atau D IV memiliki perilaku yang baik sebanyak 108 responden (91,5\%). Hal ini menunjukkan sebagian besar bidan desa di Kabupaten Sragen dengan standar pendidikan yang sesuai akan memiliki perilaku kesehatan yang baik terutama mengenai pencegahan kanker leher rahim. 
Tabel 6. Hubungan lama kerja bidan dengan perilaku terhadap pencegahan kanker leher rahim

\begin{tabular}{lccr}
\hline \multirow{2}{*}{ Lama Kerja } & \multicolumn{2}{c}{ Perilaku } & \\
\cline { 2 - 3 } & Baik & Buruk & \\
\hline \multirow{2}{*}{$<10$ tahun } & 58 & 5 & P $=0,822$ \\
& $(49,15 \%)$ & $(4,2 \%)$ & \\
\hline \multirow{2}{*}{$\geq 10$ tahun } & 50 & 5 & \\
& $(42,3 \%)$ & $(4,2 \%)$ & \\
\hline
\end{tabular}

Hasil penelitian menunjukkan bahwa perilaku bidan desa terhadap pencegahan kanker leher Rahim tidak dipengaruhi oleh usia, pendidikan dan lama kerja. Hasil ini kurang sesuai dengan teori perubahan perilaku oleh Lawrence and Green bahwa perubahan perilaku dipengaruhi oleh beberapa faktor usia, pendidikan, pengalaman, tingkat pengetahuan, sosial ekonomi, lingkungan, tokoh masyarakat. ${ }^{9}$

Tabel 7. Hubungan pengetahuan bidan terhadap perilaku pencegahan kanker leher rahim

\begin{tabular}{lcc}
\hline \multirow{2}{*}{ Pengetahuan } & \multicolumn{2}{c}{ Perilaku } \\
& Baik & Buruk \\
\hline \multirow{2}{*}{ Baik } & 106 & 10 \\
& $(89,8 \%)$ & $(8,47 \%)$ \\
\hline \multirow{2}{*}{ Buruk } & 2 & 0 \\
& $(1,69 \%)$ & $(0 \%)$ \\
\hline
\end{tabular}

Dari tabel 7 menunjukkan bahwa pengetahuan yang baik akan diikuti dengan perilaku yang baik juga mengenai pencegahan kanker leher rahim, walaupun hubungan ini tidak bermakna secara statistik $(P$ value $=0,664)$.

Berikut hasil wawancara dengan bidan desa :

"...Saya menganjurkan pasien usia subur dan pernah kontak seksual untuk papsmear".
Tabel 8. Hubungan sikap bidan terhadap perilaku pencegahan kanker leher rahim

\begin{tabular}{lcc}
\hline \multirow{2}{*}{ Sikap } & \multicolumn{2}{c}{ Perilaku } \\
\cline { 2 - 3 } & Baik & Buruk \\
\hline \multirow{2}{*}{ Baik } & 103 & 9 \\
& $(87,2 \%)$ & $(7,63 \%)$ \\
\hline \multirow{2}{*}{ Buruk } & 5 & 1 \\
& $(4,24 \%)$ & $(0,85 \%)$ \\
\hline
\end{tabular}

Dari hasil tabel 8 didapatkan bahwa sebagian besar responden yang memiliki sikap yang baik maka akan memiliki perilaku yang baik pula, yaitu sebanyak 103 responden (87,2 \%) walaupun hubungan ini tidak bermakna ( $P$ value $=0,460$ ).

Dari penelitian kualitatif didapatkan temuan yang menarik yang bisa menjelaskan mengapa 7,63\% responden dengan sikap yang baik masih memiliki perilaku yang buruk:

“...Saya sudah pernah pap smear sekali, karena ada keluhan keputihan, namun karena hasilnya baik saya cuma melakukannya sekali".

“...Saya sudah pernah pap smear tapi cuma sekali, karena biayanya relatif mahal, mending uangnya digunakan untuk kebutuhan yang lain".

"...Saya sudah pernah pap smear, cuma sekali sih. Kata dokter juga baik-baik saja, jadi yaa cukup lah cuma sekali aja, kan hasilnya juga baik".

Dari 12 responden wawancara mendalam, di dapatkan 10 responden (83,3\%) tidak melakukan tes Inspeksi Visual dengan Asam Asetat (IVA), padahal mereka selalu memberi konseling pada pasien untuk melakukan tes IVA sebagai deteksi dini kanker leher rahim.

"...Saya sendiri belum pernah mencoba pemeriksaan tes IVA, karena saya malu sama teman saya sendiri kalau di periksa". 
"...Saya belum pernah di periksa tes IVA karena takut nanti hasilnya jelek, jadi mending saya tidak periksa saja daripada nanti saya tahu malah ngga bisa tidur".

"...Saya tidak periksa IVA test karena sedang program hamil".

"...Saya belum pernah di periksa iva test karena saya merasa sakit jika nanti dimasuki speculum".

\section{KESIMPULAN DAN SARAN}

Dari hasil diatas dapat disimpulkan bahwa antara pengetahuan, sikap dan perilaku bidan tidak ada hubungan. Dari hasil wawancara di dapatkan bahwa bidan yang mempunyai pengetahuan dan sikap yang baik belum tentu memiliki perilaku yang baik dalam upaya pencegahan kanker leher rahim. Pengetahuan bidan mengenai kanker leher rahims dan pencegahannya perlu ditingkatkan dengan upaya diadakan workshop dan pelatihan bagi bidan desa.

\section{DAFTAR PUSTAKA}

1. WHO. Human Papillomavirus (HPV) and Cervical Cancer. 2013. Diakses dari : http://www.who.int/ mediacentre/factsheets/fs380/en/.
2. Rasjidi, M. 2009. Epidemiologi Kanker leher rahims. Indonesian Journal of Cancer. Vol III (3): 103-108

3. Dinas Kesehatan Provinsi Jawa Tengah. Profil Kesehatan Provinsi Jawa Tengah Tahun 2012. Semarang.

4. Anonym, 2006. Konsep Kebidanan. In: Sofyan. Bidan Menyongsong Masa Depan. Pengurus pusat IBI . Jakarta. 15-84

5. Arikunto, S. 2002. Prosedur Penelitian. In: Endang. Metode Penelitian. Jakarta : Rhineka Cipta, 32-88

6. Denzin NK. Lincoln YS. 1994. Handbook of Qualitative Research, SAGE Publications (International Educational and Profesional Publisher), London. P:377-392 and 463-477

7. Sugiyono. 2011. Metodelogi penelitian Kuantitatif dan Kualitatif. In: April Nuryanto. Metode Penelitian. Bandung : Alfabeta. 28-56

8. Indrawati, A. 2010. Hubungan Pengetahuan tentang Kanker Leher Rahim dengan Motivasi untuk melakukan Pap Smear di Ruang Melati RSUP dr. Soeradji Tirtonegoro Klaten Jawa Tengah. Skripsi Sarjana Keperawatan Fakultas Kedokteran UGM.

9. Green L., Kreuter, Marshal W., 1991. Health Promotion Planning, An Education and Environmental Approach, Mountain View, Mayfield Publishing Company, 2nd Edition. 